\title{
The Effect of Using Rountable Technique on Student'S Writing Skill in Arranging Sentences
}

\section{Yetty Wirasini and Syahron Lubis}

University of Sumatera Utara, Medan, Indonesia

\section{Abstract}

This research is concerned with applying roundtable technique writing skill in arranging sentences to form simple present tense. The aim of the research is to find out if applying roundtable technique effects on students' writing skill in arranging sentences. The research is conducted by experimental method. The population of the research is XI students of SMA Swasta Dwi Tunggal Tanjung Morawa in 2018-2019 academic year. The sample consists of 60 students then divided into two groups, 30 students as experimental group and 30 students as control group. The experimental group is taught by applying roundtable technique and the control group without applying

Corresponding Author: Yetty Wirasini

Yettywirasini40@gmail.com

Received: 1 July 2019

Accepted: 18 July 2019

Published: 31 July 2019

Publishing services provided by Knowledge E

(c) Yetty Wirasini and Syahron Lubis. This article is distributed under the terms of the

Commons Attribution License, which permits unrestricted use and redistribution provided that the original author and source are credited.

Selection and Peer-review under the responsibility of the AICLL 2019 Conference Committee. roundtable technique. The researcher uses writing test as instrument of the research. The test is answered by multiple choices and arranging sentences about simple present tense.The researcher analyzes the data by using the formula of t-test commonly used. After calculating and analyzing the data, it is concluded that $t_{\text {calculate }}$ is higher than $t_{\text {table }}(5,54>2,02)$. It showed that there is a significant difference. The pre test mean score of experimental is 57,16 and post test is 84,5 , the difference is 27,34 . The value ot $t_{\text {calculate }}$ is bigger than $t_{\text {table }}(5,54>2,02)$ degree of freedom is 58 , and the level significance is 0,05 . The result is that applying roundtable technique gives significant effect on students' writing skill in arranging sentences simple presentt tense. So, It can concluded from t-test above that the hypothesis of this study is accepted.

Keywords: Roundtable technique, Writing Skill, Arranging Sentences.

\section{Introduction}

Writing is more than a medium of communication. It means that writing is not just the way to communicate to each other but also as means of ideas and emotional expressions. The word becomes permanent by writing, and as the expanding of the various memory of human being. By writing the people can see what are in someone thought because it is visible and permanent whereas spoken words disappear after they are spoken. Different from spoken words, writing quality can be examined and tested. So writing is a way of remembering and a good way to do the communication because by writing, the writer really thinks about what to be communicated by writing it. 
Writing is very important in today's world life, as Graham (2006) states that students who do struggle significanly with writing, and adults who cannot or will not engage in writing, are at a terrible disadvantage in today's world. If someone does not write well he will find the difficultiesin learning process, education and employment.

Students in Indonesia have been taught writing course since they are in the firstclass of Junior High School. But, it is found that they face some difficulties in writing. As Hazanah (2003) found that commonly, students are difficultin starting the writing, as they get confused about what to write and also about how to generate ideas. This is because of the lack of knowledge about the steps on writing was procedural factors that cause the difficultiesfor all students. And the most important thing is that, writing is usually get least attention in teaching learning in classroom, which make students are rarely exposed to writing.

This matter also happens to the students in SMA Swasta Dwi Tunggal. As the researcher observes the students in that school, the researcher finds that many students think that it is because the ability in writing can be achieved through a lot of practice and process. Most of researchers recognizes that this difficulty in writing is caused by the complexity of writing. (Boardman, 2008: 5).

The researcher gets the score in writing course is low. The scores take from the written test in the final semester. Students as beginners in learning English usually make many mistakes in sentences especially in making of sentences present tense. The researcher will try to investigate and identify the actual problems especially in building English sentences. Moreover,She will try to find out why students have many problems in writing, analyze accurately the difficulties that our students have in learning each pattern, as well as discover remedies for these problems and suggest solutions.

Sometimes they find difficulties in finding idea, they do not know how to arrange the vocabulary that they have into good sentences. In this case, the teacher should find out solution by creating efficient and effective techniques of teaching writing that can make the writing class more interesting, exciting, and enjoyable. It can be done by choosing the material appropriate with the students and take a techniques in increasing the writing ability of the students. One of them is using cooperative learning type "Roundtable Technique".

The law ability the students conclude based on five criteria of writing, are: content, organization, vocabulary, language use, and mechanic. It means that the students need something difference which can improve their motivation in English learning process. The researcher will use Roundtble Technique in her research because it can help the students to change their knowledge in write good sentences. 
One reason for learning to write is to transmit ideas to people, especially to those who are a distance in time and space. Another reason is the writing process helps you sort out and organize random thoughts, clarify what you really think and develop ideas. That is why people want to write because writing can be a media to communicate with others in one community or wider world. If someone can write well, he or she can communicate with a person who is a thousand of miles away from him; understand what he means and what he feels.

Relating to the above statement, the writing skill must be given much attention in teaching language. However, the writing skill is a complex and sometimes difficult to teach; it requires mastery of not only grammatical and rhetorical devices but also of the conceptual and judgment element. There are many various skills necessary for good sentences. It has five general components of main ideas. They are language use, mechanical skills, statement of content, stylistic skill, and judgment skill (Heaton, 1999).

Furthermore, the ability of mastering the sentence structure enables the students to combine, expand, and shorten the sentence and further enables them to produce perfect English with some various ways. Mastering the sentence structure will be understandable for the listeners and readers. If the students have good skills in sentence construction, they will be able to make and arrange the sentence into a paragraph, which is the beginning of how to be a good writer.

\section{Literature Review}

\subsection{Writing}

Hyland (2004) explains that writing is a way to share personal meanings. The people construct their own views on topic. They will share their views on atopic to each other then. A person's views may be different from other people'sviews. It depends on their belief.

Therefore, when constructing their views ideas,the people have to make it understandable and acceptable. Furthermore, writing skill is a person's ability to express his/her mind and feeling which is expressed in a writtenlanguage, in graphic symbols so that the readers are able to understand the message inside. From the statement, it can be said that writing is a skill where the writer can set his idea down in the form of words, sentences, and paragraphs which are easy to understand for the readers. Writing is a process in describing a language that can be understood by others, i.e readers. It means that writing needs a process, so that theidea can be understandable and expressed 
smoothly.Brown (2001) illustrates that writing is like swimming. When peoplewant to be able to swim, they must have like an instructor to show them basicways or tricks to swim, although the instructor is only their parents or their friends(not professional instructors).

After they get the basic ways to swim, they will develop based on their own style. The more chance they get to swim, the moreperfect they will be. Writing has similar illustration with swimming. At the firsttime, there will be teachers who guide students to write. They will show studentsprinciples of writing. After students get the principles, they will try to developtheir writing according to their own style. Students should get sufficient writing practices to acquire writing ability. These practices are aimed to stimulate their skill in expressing thoughts in a good passage. It is impossible to be able to write the researcher and effectively without sufficient practice.

From all the statements above, it can be concluded that writing is anactivity of thinking after which it is expressed into graphic symbols, in acommunicative written language. In expressing the thought into a written language, feeling plays an important role as well, so that the products will be easily understood and enjoyed by the readers.

\subsection{Steps of writing}

There are some steps in writing. There are planning, drafting, editing and final draft (Harmer, 2004). The first is planning. The planning is a very important step. In this step, the writers decide the topic. The topic is selected depending on the purposes of the writers itself. In this step, the writers brainstorm their ideas about all things that are related to the topic and take notes about the ideas. The last, the writers make outlining of their writing. The writers write the main points and sub points in the order in which they plan write about them.

The second is drafting. The writers begin to write. The outline will be guided for the writers to write in the writing process. The writers should develop their ideas in the paragraph. The paragraph should be coherent between one with another.

The third is editing. The writers edit their draft to improve the content and the style of their writing to make it more interesting and readable. In the editing process, the writers should check their writing. When writers edit their draft, they will make some changes. They often add a whole paragraph or more,take out one or more paragraphs, change the order of paragraph, add or take out whole sentences, rewrite the sentences, change the vocabularies and so on.

The last is final draft. This step is very important in the writing process. In this step, the writer should rewrite their draft. The writer should take attention to detail of all words, 
sentences and paragraphs. It is the final paper of the writers writing and the result of the writing process.

Harmer (2004: 31) writing is a process consisting of a number of steps:

1. Thinking about a topic.

2. Freely jotting ideas about the topic.

3. Narrowing the topic and writing it in one sentence selecting and dropping ideas.

4. Selecting and dropping ideas.

5. Arranging ideas in a plan.

6. Writing a first draft.

7. Rethinking and revising as necessary.

8. Writing a new draft.

9. Proofreading for grammar and spelling.

Based on statement above, the researcher concludes that writing was a process a paragraph that involves several steps. Since writing was a complex process, the teacher should consider facilitating the students with appropriate learning experience of writing so that they were encouraged to explore an experiment their ways of writing. Students will make a good writing if they follow steps of the process of writing itself.

Writing is a skill needs a process in expressing an idea or opinion that is written on a paper or other media. A good writing process can be done by preparing and determining the subject, then making drafts, and revising or post-writing.

\subsection{Writing goals}

1. Writers are independent when they are able to write without much assistance.

2. Writers gain comprehensibility when they can write, So that it can be read and understood by themselves and other.

3. Writers are fluent when they are able to write smoothly and easily as well as understand.

4. Writer again creativity when they can write their own ideas. Not copying what has already been written, so that they can be read understood. 
Everyone always have a definite purpose when they write. The term purpose refers to a person's reason for writing suchas to inform, entertain, explain, or persuade

1. Writing to inform

Writing to inform is another key essay writing style for students to master. It involves different skills and techniquesfrom other essay formats as it is more focused on providing clear, accurate information than on giving the writer's point of view or argument. It is very important, both in writing to inform and more general informative essay writing, to follow the simple steps bellow to getting the style just right.

2. Writing to persuade

Writing to persuade is one of the easiest forms of writing to do well because there are a variety of simple techniques you can use your answer stand for out. Make sure you learn these techniques so that you can take full advantage if you happen to get a persuasive question in the exam.writing is to persuade more strongly argues for your personal opinion throughout the essay. The points of writing persuade are to make the readers believe what you want to believe / to make them agree with you and to attack the arguments against your position and show that they are weak/unconvincing.

3. Writing to entertain

To entertain is to tell a funny story or to tell what a person or place is line in an interesting is funny way. Writing to entertain has the goal that is to provide an emotional experience for the reader.

\subsection{The quality of good writing}

There are some qualities of good writing (Wilson, and Andrada, 2016.), they are:

1. Ideas; your ideas are the heart of your writing. Ordinary ideas turn into ordinary writing. Intriguing ideas turn into intriguing writing. Whatever you write, give it a fresh perspective. Use details to help readers to see your topic in a new way.

2. Organization; a writing must be present in way that readers can follow and understand every organization. Choose a structure and use it consistently throughout the writing. Make sure that readers have the information they need to understand the new information and the new ideas in your writing. Conclude your writing by wrapping up any loose ends and leaving the reader with something to think about. 
3. Voice; when you call a friend on the telephone, your friend can probably recognize your voice, even though he or she can't see your face. Make your writing voice as distinctive as your speaking voice. Observe the convention of written English, bujt give your riting a personal touch that makes it your own.

4. Word choice; the words you choose influence the effectiveness of your writing. Choose vivid and precise words to communicate your experiences. Use words with powerful connotations to communicate feelings and reactions. It involves more than learning a lot of new words. It involves learn into use the words you already know.

5. Sentences fluency; effective writing has a rhythm-a flow. Write sentences that can be read aloud without difficulty or awkwardness.

6. Conventions; conventions refer to the grammatical correctness of a writing. Don't let errors in grammar, usage, mechanics and spelling interfere with message. Carefully proofread all your writing.

\subsection{Teaching writing}

The importance given to write differs from teaching situation to teaching situation. In some cases it shares equal billing with the other skills; in other curricula it is only used, if at all, in its writing for learning role where the students write predominately to argument their learning of grammar and vocabulary of the language. Partly, because the nature of the writing process and also because of the need for accuracy in writing, the mental processes that a student goes through what they know in their minds and even consult dictionaries, grammar books, or other reference material to help them. "writing encourages students to focus on accurate language use, because they think as they write, it may well provoke language development as they resolve problems with the writing puts into their minds" (Harmer, 2004: 31).

\section{Research Method}

\subsection{Research design}

This research uses quantitative method where the study design is to test hypothesis through the use of objective instruments and statistical analysis. There are two kinds of test and questionnaire as the instruments of the research. Pre test which gives to 
the students before the researcher gives the treatment and post test which gives to the students after the students get the treatment. The test consists of fifteen questions which are divided into two parts. Each part consisted of 10 and 5 questions. In the first part each item in the form of multiple choice question consisting of four answers ( $A, B, C$, and $D$ ) and the students must choose one which is the right answer. In the second one each item only arranging sentences in simple present tense that consist from five question.

This research also deals with two groups of samples an experimental group and a control group. The experimental group studies by using the roundtable technique and the control studies by using direct instruction strategy.

\section{Result and Discussion}

\subsection{Roundtable technique}

\subsubsection{Definition of roundtable technique}

Based on Barkley (2005), Roundtable is a technique where the students take turn responding to a prompt by writing one or two words or phrases before passing the paper along to others who do the same. It is a written version of Round Robin Brainstorming. It can lead students to be active and responsible in their group. So, each member of the group is responsible for instruction given.

Roundtable Strategy is a useful technique to use in writing activity. It canbe a strategy which helps students to brainstorm their ideas or their thoughts aboutthe topic and review it in a group. Students have to be active and follow the rules of this activity. It is also can be an active learning strategy. This means that the students' role is bigger than the teacher in the classroom. In this technique,students do not listen the teacher's explanation all the time; they also have to explore their ideas and participation to their group. It expected to give different atmosphere in teaching-learning can motivate students to follow the lesson well.

Moreover, Roundtable Strategy is a good strategy to make students briefer to express themselves to express their ideas and generated it with each other (Barkley, 2005). Before implementing the Roundtable Strategy, the teacher should make a group of four students and let the students sit in their group's desk. The teacher should also prepare a blank paper for the students to write. 


\subsubsection{Procedures of roundtable technique}

Roundtable Technique is originally designed for teaching writing, but in practice this technique can be developed to teach all kinds of subjects and skills.

According to Kagan (1994)," the steps of roundtable technique are":

1. Grouping-the teacher asks the students to sit in a group of four students;

2. Preparing-the teacher gives the groups similar theme;

3. Brainstorming the teacher asks the member of the groups to write words or phrases related to the theme.

4. Writing-the group writes a text using the words/phrases written;

5. Presenting-each group presents their writing.

6. Evaluating-the teacher asks each group to make correction.

7. Revising-each group revises their work/writing. The researcher did those steps in teaching writing to make the students can do the learning processes easil

Moreover, Kagan (1994) describes that" in team of Roundtable Technique, each student writes a response on his own piece of paper. Students then pass their papers clockwise so each teammate can add to the prior responses".

\subsubsection{Benefit of using roundtable technique}

Roundtable ensures equal participation among group members and exposes students to multiple viewpoints and ideas. By having students write their ideas as opposed to speaking them, Roundtable help students to focus their attention, gives students quiet time to think about their responses, and provide an accumulative record. In Roundtable, students were able to build upon each other's contributions. It encourages students to adjust their writing (in areas like content,conventions, style, and vocabulary) as they respond and react to the comment of the writers that preceded them (Barkley, 2005: 75).

\subsubsection{Disadvantages of using roundtable technique}

Barkley (2005) states that Roundtable is one of the brainstorming techniques called as the natural way in developing the writing. It is only used for fairly simple tasks, not for 
the complex or reasoning ones. It is only the surface of technique in teaching writing, so it does not a good technique when it is used to write an easy writing which has long Paragraph. Sometimes the learners are confused how to use it because the learners confused where to start writing.

Besides, the learners do this way under pressure to make this technique as an affective way. Time is wasted and students will likely get bored.

\section{Conclusion}

After analyzing the data,the conclusions are as follows:

1. The result t-observed 5,54 is larger than t-table 2,02 . It means that $\mathrm{H}_{a}$ is accepted and $\mathrm{H}_{O}$ is rejected. The students who are taught by using roundtable technique is better than using direct instruction strategy. Roundtable technique can be produce many ideas and it can guide to better understanding of the subject and the students can produce a good sentences because the students can write more effective with team work expecially in making and arranging sentences.

2. Roundtable technique is one resolution to help students to be more actively, be spirit,love with their subject and it can help the students to learn effectives in the classroom. And roundtable technique can be used to develop the student's writing skill in arranging sentences developing their ideas.

\section{References}

[1] Barkley, E. F.etal. 2005.CollaborativeLearningTechniques:A Handbook for ““““”“Collage Faculty. San Fransisco: Jossey-Bass.

[2] Boardman, C.A. 2008. Writing to Communicate Paragraph and Essay 10 Bank “ Street, White Plains, NY 10606: Pearson Education.

[3] Graham, S. 2006. Writing in P. Alexander \& P. Winne (Eds). Handbookof “،u“،“'Educational Psychology (pp.457 -478). Mnawah, NJ: Erlbaum.

[4] Harmer, J.2004.How to Teach Writing. Essex: Pearson Education Ltd.

[5] Harmer, J. 2004. How to Teach Writing. Pearson Education Limited: Longman.

[6] Hazanah, C.Y. 2003.The difficulties in Rendering Complex Sentencesin “"'Interpreting Indonesian Discourse into English Unpublished Academic “"“Paper. Bandung: Indonesia University of Education. 
[7] Heaton,J.B.1999. Written English Language Text New York: Language group ““،“،“‘UK limited.

[8] Heaton,J.B.1989. Written English Language Text New York: Language group ““‘،““'UK limited.

[9] Hyland, K. 2004.Second Language Writing. NewYork: Cambridge University.

[10] Kagan, S.1994. Cooperative learning. San Clemente, CA: Kagan Cooperative Learning.

[11] Wilson, Joshua and Andrada, Gilberta. 2016. Using Automated Feedback to Improve Writing Quality: Opportunities and Challenges. ResearchGate. From https://www.researchgate.net/publication/289528421_Using_Automated_Feedbac k_to_Improve_Writing_Quality_Opportunities_and_Challenges 